https://doi.org/10.15407/ujpe66.9.803

E. OVODOK, ${ }^{1}$ M. IVANOVSKAYA,${ }^{1}$ D. KOTSIKAU,${ }^{2}$ V. KORMOSH,${ }^{3}$ P. PYLYP,${ }^{4}$ V. BILANYCH ${ }^{4}$

${ }^{1}$ Research Institute for Physical-Chemical Problems of the Belarusian State University (Minsk 220030, Belarus)

2 Belarusian State University (Minsk 220030, Belarus)

${ }^{3}$ Research Institute of Analytical Technique of Uzhhorod National University (Uzhhorod 88000, Ukraine)

4 Department of Applied Physics, Uzhhorod National University (Uzhhorod 88000, Ukraine)

\title{
STRUCTURAL CHARACTERIZATION AND GAS SENSING PROPERTIES OF NANO-SIZED TIN DIOXIDE MATERIAL SYNTHESIZED FROM TIN(II) SULFATE
}

\begin{abstract}
Structural features, surface condition, and gas-sensing properties of the nanocrystalline $\mathrm{SnO}_{2}$ powders synthesized from $\mathrm{SnSO}_{4}$ precursor by different methods have been studied. XRD, TEM, BET, and FTIR methods were used for the samples characterization. The gas sensors were fabricated by the thick-film technology from the synthesized $\mathrm{SnO}_{2}$ powders. The responses of the sensors toward $\mathrm{CO}$ and $\mathrm{CH}_{4}$ gases are measured. It is revealed that the preoxidation of $\mathrm{SnSO}_{4}$ powder with concentrated sulfuric acid before the hydrolysis results in the lower particle size, higher surface area, improved adsorption activity, and higher sensitivity to reducing gases $\left(\mathrm{CO}, \mathrm{CH}_{4}\right)$ of the synthesized $\mathrm{SnO}_{2}$ materials, than in the case of the $\mathrm{SnO}_{2}$ materials obtained without the preoxidation stage.

Keywords: $\mathrm{SnO}_{2}, \mathrm{SnSO}_{4}$, FTIR spectroscopy, thick-film sensor, CO, $\mathrm{CH}_{4}$.
\end{abstract}

\section{Introduction}

Tin dioxide is widely used as a solid-state gas sensor material due to its physico-chemical properties, chemical stability, and relatively low cost [1-3]. The thickfilm technology is extensively used for the fabrication of gas sensors [4-6]. A finely dispersed $\mathrm{SnO}_{2}$ powder is required to obtain gas sensors of a good quality by the thick-film technology. N. Yamazoe and coworkers showed that the sensors fabricated from tin dioxide with particle sizes in the interval from 4 to $10 \mathrm{~nm}$ generally possess a higher gas sensitivity, than the sensors fabricated from coarser $\mathrm{SnO}_{2}$ particles [7,8].

One of the most commonly used methods for the production of $\mathrm{SnO}_{2}$ materials is the sol-gel approach with a $\mathrm{SnCl}_{4}$ solution as a precursor [9-11]. However, N. Yamazoe revealed that using $\mathrm{SnCl}_{4}$ precursor within the unmodified sol-gel method does not provide the possibility to obtain an $\mathrm{SnO}_{2}$ powder calcinated at $600{ }^{\circ} \mathrm{C}$ with the sizes of particles smaller

(C) E. OVODOK, M. IVANOVSKAYA, D. KOTSIKAU,

V. KORMOSH, P. PYLYP, V. BILANYCH, 2021

ISSN 2071-0194. Ukr. J. Phys. 2021. Vol. 66, No. 9 than $15 \mathrm{~nm}$ [7]. C. Xu and coworkers showed that the crystallite size of $\mathrm{SnO}_{2}$ can be stabilized against the thermal growth, when the stannic acid gel was impregnated with a small amount (5 at. \%) of a foreign metal oxides [8]. In our work, we suggest the $\mathrm{SnO}_{2}$ synthesis route that allows stabilizing the $\mathrm{SnO}_{2}$ crystallite size during a thermal treatment without adding extraneous metal oxides.

G.W. Wang and coworkers showed that the addition of $\mathrm{SO}_{4}^{2-}$ ions to $\operatorname{tin}(\mathrm{IV})$ hydroxide during the $\mathrm{SnO}_{2}$ synthesis from $\mathrm{SnCl}_{4}$ caused a notable increase in the surface area of the calcinated oxide [12]. However, the residual chloride ions can degrade the gas- sensitive properties of the $\mathrm{SnO}_{2}$ sensor materials. H.C. Chiu and C.S. Yeh showed that the presence of $\mathrm{Cl}^{-}$ions change the number of the oxygen species in $\mathrm{SnO}_{2}$ and decrease the sensitivity of the sensor to ethanol [13]. Thus, using tin sulfate salts as a precursor is reasonable. The presence of $\mathrm{Sn}(\mathrm{IV})$ ions in a solution is necessary for the formation of sols, which allows one to get $\mathrm{SnO}_{2}$ thin film samples and fine dispersed $\mathrm{SnO}_{2}$ powders. However, tin(IV) sulphate 
is easily hydrolyzed by crystal water and humidity of air. For this reason, $\mathrm{SnSO}_{4}$ salt was chosen as an initial precursor.

In addition, sulphate ions can modify the surface and change the adsorption and catalytic properties of metal oxides. K. Arata and M. Hino found that $\mathrm{SnO}_{2}$, $\mathrm{TiO}_{2}$, and $\mathrm{ZrO}_{2}$ calcinated oxides, which were synthesized in the presence of sulphate ions, are characterized by a high concentration of acid centers. The ratio between Lewis and Bronsted acid sites on these oxides can change under a moisture treatment [14]. Surface acid sites influence the catalytic activities of materials. The surface sulfate groups can be directly involved in the process of gas adsorption, or they can act as an activator of reagents in catalytic reactions. An improvement of the sensitivity of $\mathrm{Fe}_{2} \mathrm{O}_{3}-$ $\mathrm{SnO}_{2}$ materials to $\mathrm{CH}_{4}$ under the influence of $\mathrm{SO}_{4}^{2-}$ ions has been established by M. Takana and coworkers [15].

The present work is aimed at the characterization of the structure and gas-sensing properties of $\mathrm{SnO}_{2}$ materials that are prepared by different routes from the $\mathrm{SnSO}_{4}$ precursor and are suitable for the production of thick film gas sensors.

\section{Material and Methods}

Two methods of synthesis of a $\mathrm{SnO}_{2}$ powder from the $\mathrm{SnSO}_{4}$ precursor were used.

Method I. The $\mathrm{SnO}_{2}$ powder was obtained by the hydrolysis of a $\mathrm{SnSO}_{4}$ solution and a subsequent thermal treatment of the precipitated oxyhydroxide. Here, $100 \mathrm{ml}$ of a $\mathrm{SnSO}_{4}$ solution $(C=50 \mathrm{~g} / \mathrm{l})$ was prepared by dissolving the freshly recrystallized $\mathrm{SnSO}_{4}$ salt in distilled water acidified with sulfuric acid ( $\mathrm{pH} 2$ ). An ammonia solution $(C=5$ wt. \%) was added dropwise to a $\mathrm{SnSO}_{4}$ solution until $\mathrm{pH} 8$ was reached.

The obtained precipitate was separated by the centrifugation and washed 3 times with distilled water. $50 \mathrm{ml}$ of distilled water and $0.1 \mathrm{ml}$ of concentrated sulfuric acid were added to the precipitate. Then the suspension was ultrasonificated $(f=22 \mathrm{kHz}, P=$ $=130 \mathrm{~W})$ for $2 \mathrm{~min}$. The resultant precipitate was dried at $50{ }^{\circ} \mathrm{C}$ and calcinated for $1 \mathrm{~h}$ at $600{ }^{\circ} \mathrm{C}$ $\left(\mathrm{SnO}_{2}(\mathrm{I})\right)$.

Method II. The preoxidation of $\mathrm{SnSO}_{4}$ salt with concentrated sulfuric acid was carried out before the hydrolysis. Typically, $5 \mathrm{~g}$ of the freshly recrystallized
$\mathrm{SnSO}_{4}$ powder was added to $5.5 \mathrm{ml}$ of concentrated $\mathrm{H}_{2} \mathrm{SO}_{4}$ acid. The suspension was heated at $200^{\circ} \mathrm{C}$ during $10 \mathrm{~min}$. At the end of the reaction, the solution was diluted with distilled water up to $100 \mathrm{ml}$. Then an ammonia solution $(C=5 \%)$ was added dropwise until $\mathrm{pH} 8$ was reached.

The obtained precipitate was separated by the centrifugation and washed 3 times with distilled water. $50 \mathrm{ml}$ of distilled water and $0.1 \mathrm{ml}$ of concentrated sulfuric acid were added to the precipitate. Then the suspension was ultrasonificated $(f=22 \mathrm{kHz}, P=$ $=130 \mathrm{~W}$ ) for $2 \mathrm{~min}$. A transparent sol was obtained under such treatment. The resultant sol was dried at $50{ }^{\circ} \mathrm{C}$ and calcinated at $600{ }^{\circ} \mathrm{C}\left(\mathrm{SnO}_{2}(\mathrm{II})\right)$. Method II was developed by us for obtaining a highly dispersed calcinated $\mathrm{SnO}_{2}$ powder.

The phase composition of the materials was characterized by the X-ray diffraction (XRD) analysis. The XRD analysis was carried out on a PANalytical X'Pert PRO MRD (multipurpose research diffractometer, Holland) with a modular construction using $\mathrm{Cu} \mathrm{K} \mathrm{K}_{\alpha}$-radiation. The fine structural features of the $\mathrm{SnO}_{2}$ crystallites were revealed by the transmission electron microscopy (TEM). The TEM examinations were performed on a $L E O 906 E$ transmission electron microscope. The specific area $\left(S_{\mathrm{BET}}\right)$ was calculated by the BET (Brunauer-Emmett-Teller) method from nitrogen adsorption isotherms measured by a Gemini V2.00 surface analyzer (Micromeritics Instrument Corp.) at $-196{ }^{\circ} \mathrm{C}$. The state of the surface of samples was examined by the Fourier transform infrared spectroscopy (FTIR). The FTIR analysis was carried out on an AVATAR FTIR-330 spectrometer supplied with a smart diffuse reflectance accessory in the wavenumber range from 400 to $4000 \mathrm{~cm}^{-1}$.

The gas sensors were fabricated by the thick-film technology. The $\mathrm{SnO}_{2}$ powders were grinded thoroughly with ethanol in an agate mortar. Then the obtained paste was deposited onto polycrystalline $\mathrm{Al}_{2} \mathrm{O}_{3}$ substrates $\left(1.6 \times 1.6 \times 0.25 \mathrm{~mm}^{3}\right)$ supplied with a $\mathrm{Pt}$ interdigitated electrode on the front side and a Pt-heater on the rear side. The sensor elements were annealed at $570{ }^{\circ} \mathrm{C}$ for $3 \mathrm{~h}$ in air. The thickness of the oxide sensitive layer was about $15 \mathrm{mkm}$.

$\mathrm{SnO}_{2}(\mathrm{I})$ and $\mathrm{SnO}_{2}(\mathrm{II})$ sensors were fabricated from the $\mathrm{SnO}_{2}$ powders synthesized by methods I and II, respectively. A contact electric potential was applied to the heater, and a resistance of the sensing layer was measured in air $\left(R_{\text {air }}\right)$ and in air-gas mixtures

ISSN 2071-0194. Ukr. J. Phys. 2021. Vol. 66, No. 9 
$\left(R_{\text {gas }}\right)$. The sensor response $(\mathrm{G})$ was calculated as $R_{\text {air }} / \mathrm{R}_{\text {gas }}$. The response measurements were carried out in air-gas mixtures with a $\mathrm{CH}_{4}$ concentration of $1000 \mathrm{ppm}$ and with a CO concentration of $1000 \mathrm{ppm}$ (30\% relative humidity) at different working temperatures. Concentration dependences of the resistances ofsensors at the CO detection were obtained at determined optimal operation temperatures.

\section{Results and Discussion}

\subsection{Structure, morphology, and surface state}

The X-ray diffraction patterns of the as-prepared and the annealed at $600{ }^{\circ} \mathrm{C}$ samples are shown in Fig. 1. The structural parameters of the samples are summarized in Table. According to the XRD data, the as-prepared sample synthesized by method I contains the $\mathrm{Sn}_{6} \mathrm{O}_{4}(\mathrm{OH})_{4}$ phase (JCPDS 84-2157) and $\mathrm{SnO}_{2}$ rutile phase (JCPDS 88-0287).

The as-prepared sample synthesized by method II is characterized by wide diffraction peaks assigned to the $\mathrm{SnO}_{2}$ rutile phase (JCPDS 88-0287). The rutile phase predominates in the all samples calcinated at $600{ }^{\circ} \mathrm{C}$. Traces of the $\mathrm{SnO}$ phase were additionally observed in the $\mathrm{SnO}_{2}(\mathrm{I})$ sample. The width of diffraction peaks in the patterns of the $\mathrm{SnO}_{2}$ (II) sample is much higher, than in the case of $\mathrm{SnO}_{2}(\mathrm{I})$ sample. The average size of the rutile $\mathrm{SnO}_{2}$ crystallites was estimated by the Debye-Scherrer equation from the width of the (110) reflexion. The $\mathrm{SnO}_{2}(\mathrm{I})$ sample is characterized by an average crystallite size of about $24 \mathrm{~nm}$. The $\mathrm{SnO}_{2}$ (II) sample consists from smaller crystallites $(5.5 \mathrm{~nm})$. The lattice parameters were calculated for the calcinated $\mathrm{SnO}_{2}$ samples. The unit cell parameters of the $\mathrm{SnO}_{2}(\mathrm{I})$ sample correspond well to the reference data $(a=0.4738 \mathrm{~nm}, c=0.3187 \mathrm{~nm})$ [16]. In contrast, the a parameter of the $\mathrm{SnO}_{2}$ (II) sample is slightly lower $(0.4723 \mathrm{~nm})$, and the $c$ parameter is slightly higher $(0.3199 \mathrm{~nm})$, than the values given in the literature [16]. The formation of a defective lattice is caused by the influence of sulphate groups under the dehydration and crystallization processes of initial particles during the synthesis of the $\mathrm{SnO}_{2}$ (II) sample.

According to the TEM data, the $\mathrm{SnO}_{2}(\mathrm{I})$ and $\mathrm{SnO}_{2}$ (II) samples are polycrystalline (Fig. 2). The particles have a similar morphology close to the spherical one. However, they are characterized by differ- $a$

$$
\begin{aligned}
& \text { *- } \mathrm{SnO}_{2} \\
& \mathrm{H}-\mathrm{Sn}_{6} \mathrm{O}_{4}(\mathrm{OH})_{4}
\end{aligned}
$$
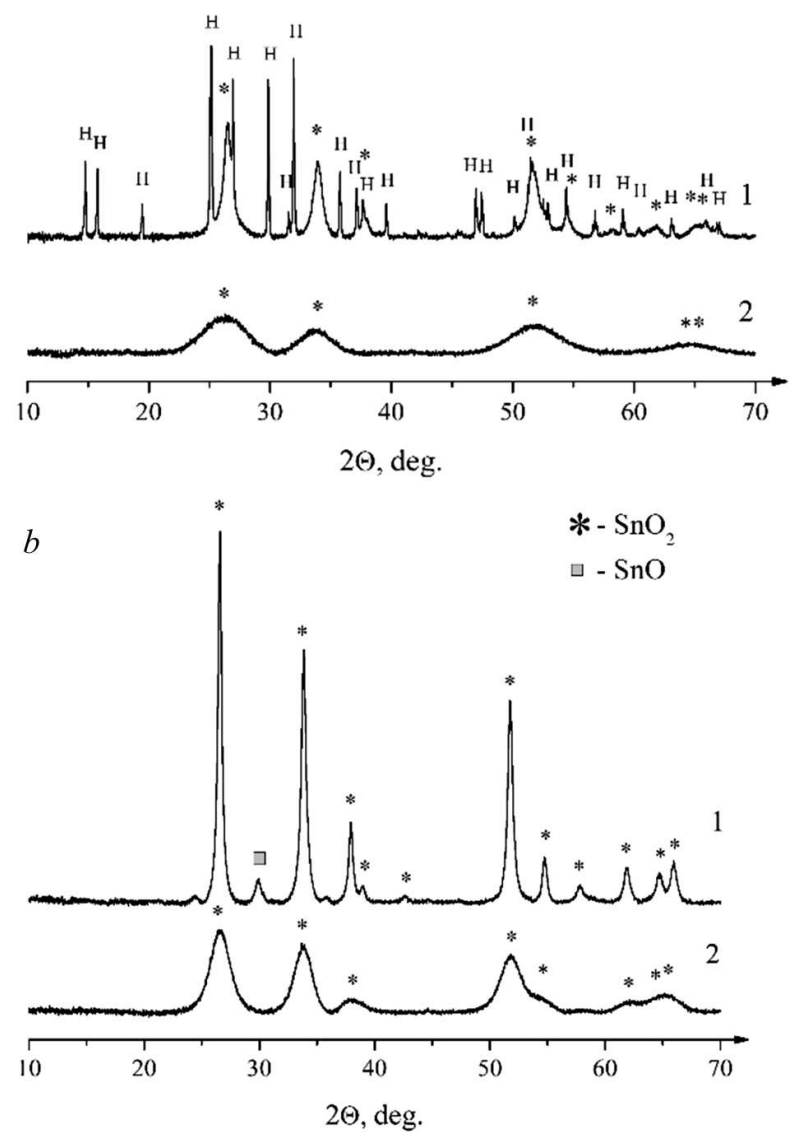

Fig. 1. X-ray diffraction patterns of as-prepared $(a)$ and calcinated at $600{ }^{\circ} \mathrm{C}(b)$ samples synthesized by method I (1) and method II (2)

ent sizes. The particle size estimated for the $\mathrm{SnO}_{2}$ (II) sample is $5.5 \mathrm{~nm}$, and that for the $\mathrm{SnO}_{2}(\mathrm{I})$ sample is $27 \mathrm{~nm}$. The TEM data are in agreement with the crystallite size calculated from XRD patterns.

The specific surface area of the samples was measured by means of the BET analysis, which shows that the surface areas are $17.9 \mathrm{~m}^{2} / \mathrm{g}$ and $70.4 \mathrm{~m}^{2} / \mathrm{g}$ for $\mathrm{SnO}_{2}(\mathrm{I})$ and $\mathrm{SnO}_{2}(\mathrm{II})$ powders, respectively. Thus, method II allows one to synthesize a $\mathrm{SnO}_{2}$ powder, which is characterized by a high surface area and a low crystallite size after the calcination at $600{ }^{\circ} \mathrm{C}$.

The described structural differences of the $\mathrm{SnO}_{2}$ samples are determined by the chemical processes, which take place during the syntheses. 
Structural characteristics of the $\mathrm{SnO}_{2}$ samples synthesized from $\mathrm{SnSO}_{4}$ by methods I and II

\begin{tabular}{|c|c|c|c|c|c|c|}
\hline $\begin{array}{c}\text { Method of } \\
\text { synthesis }\end{array}$ & $\begin{array}{c}\text { Phase composition } \\
\text { of as-prepared } \\
\text { samples }\end{array}$ & $\begin{array}{c}\text { Phase composition } \\
\text { of samples calcinated } \\
\text { at } 600{ }^{\circ} \mathrm{C}\end{array}$ & $\begin{array}{c}d_{\text {aver }}, \mathrm{nm} \\
(\mathrm{XRD})\end{array}$ & $\begin{array}{c}a \\
\text { parameter, } \\
\mathrm{nm}\end{array}$ & $\begin{array}{c}c \\
\text { parameter, } \\
\mathrm{nm}\end{array}$ & $\begin{array}{c}d_{\text {aver }}, \mathrm{nm} \\
(\mathrm{TEM})\end{array}$ \\
\hline Method I & $\begin{array}{c}\mathrm{Sn}_{6} \mathrm{O}_{4}(\mathrm{OH})_{4} \\
\mathrm{SnO}_{2}\end{array}$ & $\begin{array}{c}\mathrm{SnO}_{2} \\
\mathrm{SnO} \\
\mathrm{m}^{2} / \mathrm{g}(\mathrm{BET})\end{array}$ & $24 \pm 1$ & 0.4738 & 0.3187 & 27 \\
Method II & $\mathrm{SnO}_{2} \cdot x \mathrm{H}_{2} \mathrm{O}$ & $\mathrm{SnO}_{2}$ & $5.5 \pm 1$ & 0.4723 & 0.3199 \\
\hline
\end{tabular}
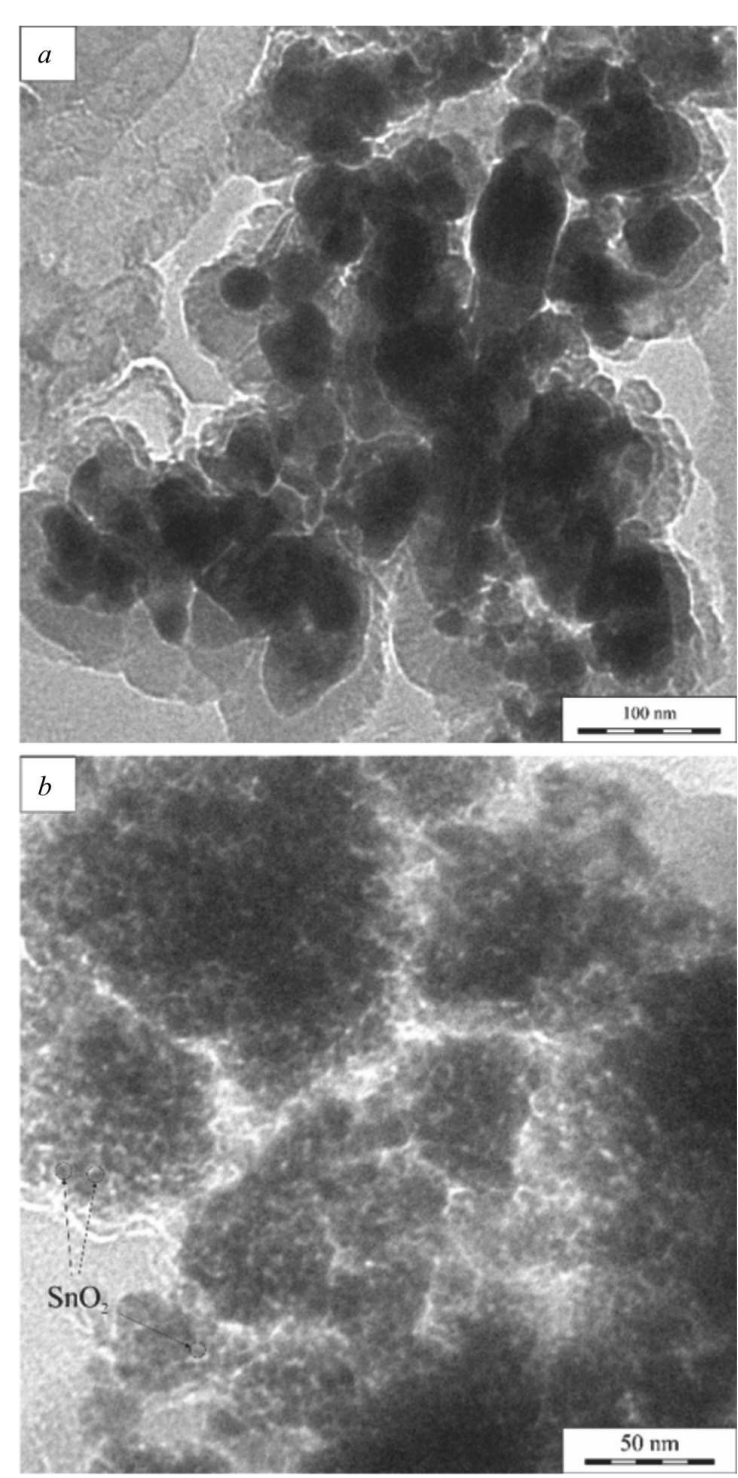

Fig. 2. TEM images of the $\mathrm{SnO}_{2}$ samples $\left(600^{\circ} \mathrm{C}\right)$ synthesized by (a) method I and (b) method II
In method I, tin(II) oxyhydroxide is precipitated by the hydrolysis of $\mathrm{SnSO}_{4}$ with an ammonia solution (Eq. (1))

$$
\begin{aligned}
& 6 \mathrm{Sn}^{2+}+6 \mathrm{SO}_{4}^{2-}+12 \mathrm{NH}_{4}^{+}+12 \mathrm{OH}^{-} \longrightarrow \\
& \longrightarrow \mathrm{Sn}_{6} \mathrm{O}_{4}(\mathrm{OH})_{4} \downarrow+12 \mathrm{NH}_{4}^{+}+6 \mathrm{SO}_{4}^{2-}+4 \mathrm{H}_{2} \mathrm{O} .
\end{aligned}
$$

The $\mathrm{Sn}_{6} \mathrm{O}_{4}(\mathrm{OH})_{4}$ crystalline phase with traces of the $\mathrm{SnO}_{2}$ rutile phase is observed in the dried precipitate. Ultrasonification during the synthesis induces a partial decomposition and the oxidation of tin(II) oxyhydroxide to $\mathrm{SnO}_{2}$. According to FTIR data, a certain amount of $\mathrm{SO}_{4}^{2-}$ groups is preserved on the surface of $\mathrm{Sn}(\mathrm{OH})_{2}$ particles after the drying (Fig. 3, a). Then tin(II) oxyhydroxide decomposes to $\mathrm{SnO}$ and oxidizes to $\mathrm{SnO}_{2}$ under the heating up to $600{ }^{\circ} \mathrm{C}$.

In method II, $\mathrm{Sn}^{2+}$ ions are oxidized to $\mathrm{Sn}^{4+}$ ions by concentrated sulfuric acid at the first stage of the synthesis (Eq. (2) and (3))

$$
\begin{aligned}
& \mathrm{Sn}^{2+}-2 \mathrm{e} \longrightarrow \mathrm{Sn}^{4+}, \\
& 2 \mathrm{H}^{+}+\mathrm{H}_{2} \mathrm{SO}_{4}+2 \mathrm{e} \longrightarrow \mathrm{SO}_{2}+2 \mathrm{H}_{2} \mathrm{O} .
\end{aligned}
$$

After this treatment, $\mathrm{Sn}^{4+}$ and $\mathrm{SO}_{4}^{2-}$ ions, as well as traces of non-oxidized $\mathrm{Sn}^{2+}$ ions, present in the resultant solution. The amount of the remained $\mathrm{Sn}^{2+}$ ions can be varied by the duration of the heating. A polymerized tin oxyhydroxide is formed during the hydrolysis of $\mathrm{Sn}^{4+}$ ions by an ammonia solution (Eq. (4))

$$
\mathrm{Sn}^{4+}+4 \mathrm{OH}^{-} \rightarrow \mathrm{SnO}_{2} \cdot 2 \mathrm{H}_{2} \mathrm{O} \text {. }
$$

The product consists of polynuclear complexes interconnected by bridging $\mathrm{OH}$-groups, in which $\mathrm{H}_{2} \mathrm{O}$ molecules are located in the coordination environment of tin ions. In the core of the generated particles, tin atoms have coordination of oxygen atoms 
similar to $\mathrm{SnO}_{2}$ oxide. Hydroxyl groups and hydrogen bonded water molecules cover the $\mathrm{SnO}_{2}$ core. Sulfate ions are intercalated in these particles and coordinated by tin ions. Annealing the sample at $600{ }^{\circ} \mathrm{C}$ induces the dehydration of the initial particles and the crystallization and growth of tin dioxide crystallites.

FTIR spectra illustrated in Fig. 3 show that sulfate ions are observed in both $\mathrm{SnO}_{2} \cdot 2 \mathrm{H}_{2} \mathrm{O}$ and $\mathrm{Sn}_{6} \mathrm{O}_{4}(\mathrm{OH})_{4}$ precipitates after the washing and drying. However, as-prepared $\mathrm{SnO}_{2}(\mathrm{I})$ and $\mathrm{SnO}_{2}(\mathrm{II})$ samples are characterized by quantitative and qualitative differences in the interval of the vibrational mode of $\left[\mathrm{SO}_{4}\right]^{2-}$ groups.

A free sulfate ion is characterized by the $\mathrm{T}_{d}$ symmetry. Two vibrational modes $\left(\nu_{3}\right.$ and $\left.\nu_{4}\right)$ of four fundamental oscillations are active in IR spectroscopy. When sulfate ions are bounded with particles, their symmetry decreases from $\mathrm{T}_{d}$ to $\mathrm{C}_{2 V}$ or $\mathrm{C}_{3 V}$, and additional bands can appear in IR spectra. The vibrational modes of bidentate bonded sulfate groups are observed in the IR spectra of the as-prepared $\mathrm{SnO}_{2}(\mathrm{I})$ sample: $\nu_{1}=948 \mathrm{~cm}^{-1}, \nu_{3}=1015,1115,1246 \mathrm{~cm}^{-1}$, and $\nu_{4}=605,661 \mathrm{~cm}^{-1}$ [17]. The bands assigned to $\nu_{1}=948 \mathrm{~cm}^{-1}, \nu_{3}=1027,1105$, and a shoulder at $1182, \nu_{4}=$ shoulders at 600 and $642 \mathrm{~cm}^{-1}$ vibrations of bidentate bonded $\left[\mathrm{SO}_{4}\right]^{2-}$ groups are detected in the FTIR spectra of the as-prepared sample synthesized by method II. The frequencies of the bands vary from sample to sample due to the difference in the energy state of surface tin atoms, which coordinate sulfate groups.

The intensities of the $\nu_{1}$ and $\nu_{3}$ vibrational modes of $\left[\mathrm{SO}_{4}\right]^{2-}$ group are considerably higher for the asprepared $\mathrm{SnO}_{2}$ (II) sample, than for the as-prepared $\mathrm{SnO}_{2}(\mathrm{I})$ sample. This is due to a higher sorption capacity of the particles in a sol, than in a precipitate. In the case of the sol, sulfate ions can be incorporated in the micelle structure and remain in the structure during the subsequent drying of the sample (Eq. (5))

$$
\left\{\left(\mathrm{SnO}_{2} \cdot n \mathrm{H}_{2} \mathrm{O}\right)_{m} \cdot 2 x \mathrm{H}^{+} \cdot(x-y) \mathrm{SO}_{4}^{2-}\right\}^{2 y+} \cdot y \mathrm{SO}_{4}^{2-} \text {. }
$$

The IR spectra of the as-prepared samples show the absorbance in the interval from 2500 to $3750 \mathrm{~cm}^{-1}$. This broad band is assigned to the stretching $\mathrm{OH}$ vibrations in hydroxyl groups and adsorbed water $(\nu(\mathrm{OH}))$ [17]. The band at $1660 \mathrm{~cm}^{-1}$ characterizes the deformation $\mathrm{HOH}$ vibrations $(\delta(\mathrm{HOH}))$. The intensity and width of the $\nu(\mathrm{OH})$ bands are noticeably
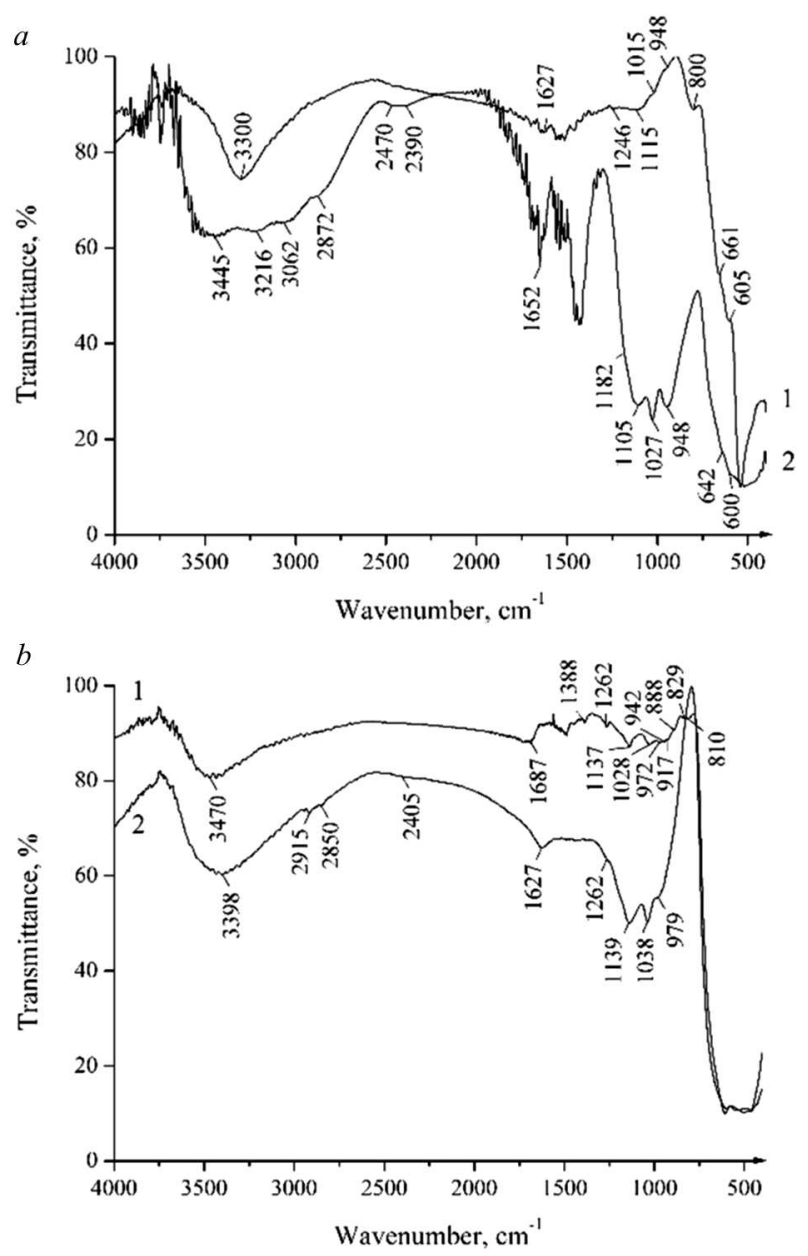

Fig. 3. FTIR spectra of as-prepared $(a)$ and calcinated at $600{ }^{\circ} \mathrm{C}(b)$ samples synthesized by method I (1) and method II (2)

higher for the as-prepared $\mathrm{SnO}_{2}$ (II) sample, than for the as-prepared $\mathrm{SnO}_{2}(\mathrm{I})$ sample. Furthermore, the local maxima of the absorption at $3445,3216,3062$, and $2872 \mathrm{~cm}^{-1}$ in the band of $\nu(\mathrm{OH})$ vibrations and additional bands for $\delta(\mathrm{HOH})$ vibrations are observed in the IR spectrum of the as-prepared $\mathrm{SnO}_{2}$ (II) sample. The features of the spectrum related to the position of the $\nu(\mathrm{OH})$ and $\delta(\mathrm{OH})$ vibrations indicate the formation of hydrogen bonds between $\mathrm{SO}_{4}^{2-}$ and $\mathrm{OH}$ groups. In addition, the presented IR data confirm the assumption that sulfate ions are incorporated in the micelle structure of $\mathrm{SnO}_{2} \cdot \mathrm{nH}_{2} \mathrm{O}$ hydrosol.

The $\nu\left[\mathrm{SO}_{4}\right]^{2-}$ bands have a low intensity in the FTIR spectrum of the calcinated $\mathrm{SnO}_{2}(\mathrm{I})$ sample, whereas a high intensity of these bands is revealed 


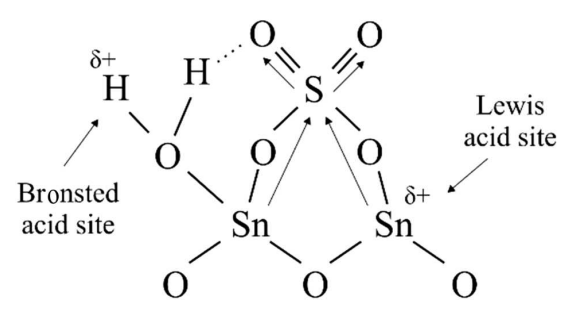

Fig. 4. Scheme of acid centers on $\mathrm{SnO}_{2}$ surface modified with sulphate groups
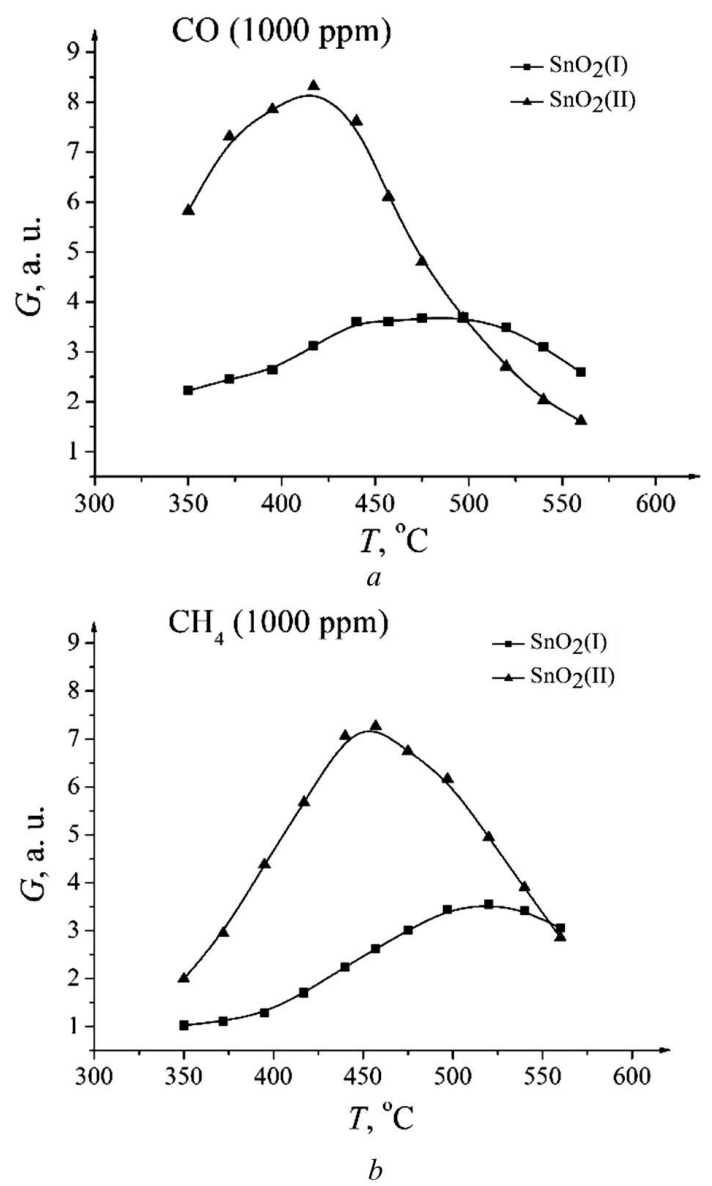

Fig. 5. The dependences of response vs working temperature for $\mathrm{SnO}_{2}$ (I and II) sensors at the detection of CO (1000 ppm) (a) and $\mathrm{CH}_{4}(1000 \mathrm{ppm})$ gases (b)

in the spectrum of the $\mathrm{SnO}_{2}$ (II) sample after the calcination (see Fig. 3, b). The triplet of $\left[\mathrm{SO}_{4}\right]^{2-}$ vibrational bands is observed for the calcinated $\mathrm{SnO}_{2}$ (II) sample, but the maxima of the bands are shifted to higher wavenumbers $\left(979,1038,1139 \mathrm{~cm}^{-1}\right)$ comparing to the as-prepared sample. Moreover, in the
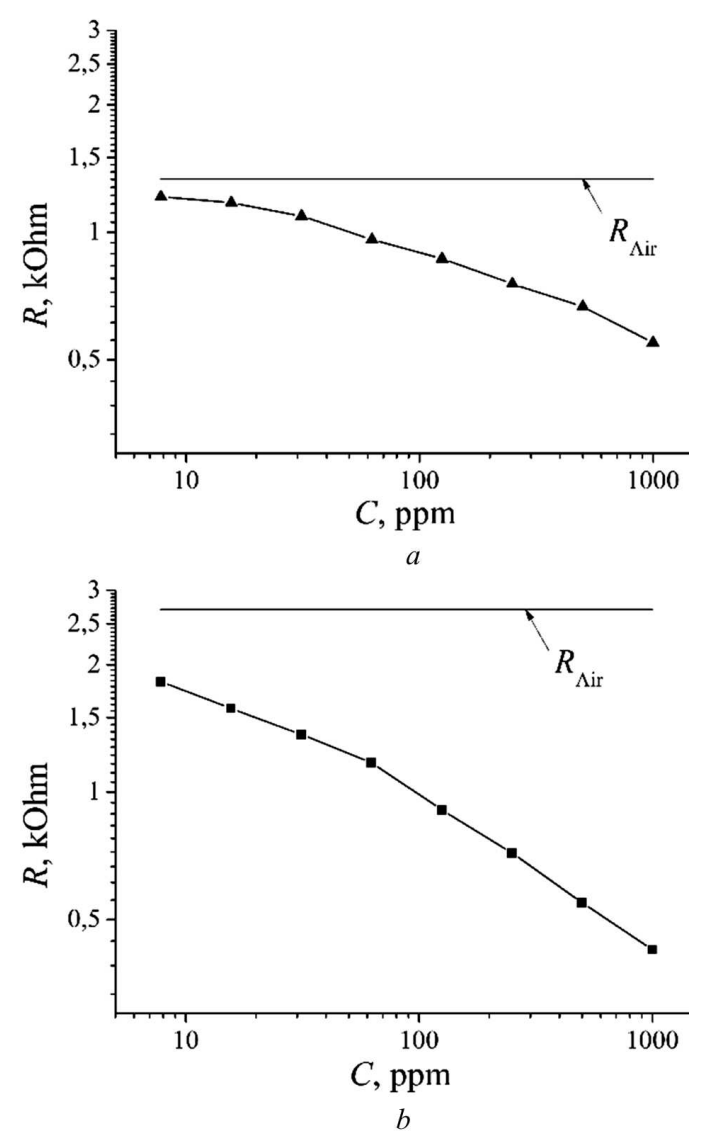

Fig. 6. Dependences of the electric resistance of $\mathrm{SnO}_{2}$ (I) sensor $(a)$ and $\mathrm{SnO}_{2}$ (II) sensor (b) on the concentration of $\mathrm{CO}$ in air

spectrum of the $\mathrm{SnO}_{2}$ (II) sample annealed at $600{ }^{\circ} \mathrm{C}$, a wide band attributed to $\nu(\mathrm{OH})$ vibrations is observed. Note that the local maxima are resolved less in this interval, than for the as-prepared sample. The adsorption maximum of the $\nu(\mathrm{OH})$ band is observed at $3470 \mathrm{~cm}^{-1}$, and the small peaks are detected at $2915,2855,2405 \mathrm{~cm}^{-1}$. These peaks indicate that hydrogen-bonded $\mathrm{OH}$ groups are presented on the oxide surface. The interaction between $\mathrm{SO}_{4}^{2-}$-ions and OH-groups influences the state of the surface adsorption centers of $\mathrm{SnO}_{2}$ oxide.

Thus, according to the IR data, the surfaces of the $\mathrm{SnO}_{2}(\mathrm{I})$ and $\mathrm{SnO}_{2}$ (II) samples contain unequal amounts of $\left[\mathrm{SO}_{4}\right]^{2-}$ groups. The as-prepared $\mathrm{SnO}_{2}$ (II) sample has a high amount of surface hydroxyl groups and adsorbed water, which forms hydrogen bonds with $\left[\mathrm{SO}_{4}\right]^{2-}$ groups. Furthermore, sulphate groups are included directly in the micelle

ISSN 2071-0194. Ukr. J. Phys. 2021. Vol. 66, No. 9 
structure. Sulphate groups influence the processes of dehydration and crystallization of oxide. As a result, the $\mathrm{SnO}_{2}$ (II) sample calcinated at $600{ }^{\circ} \mathrm{C}$ is characterized by a low particle size and a high surface area and contains a high amount of surface sulfate groups. The sulphate groups are bidentates bound with tin cations. Surface $\mathrm{SO}_{4}^{2-}$ ions create Bronsted acid sites and improve acceptor properties of the surface $\mathrm{Sn}^{4+}$ lattice cations (Lewis acid sites) due to the inductive interaction (Fig. 4). Surface acid sites are active in the adsorption and dissociation of gas molecules. Kustov and coworkers showed that the modification of $\mathrm{ZrO}_{2}$ with $\mathrm{SO}_{4}^{2-}$ anions results in a strengthening of the surface Lewis acid sites represented by low-coordinated zirconium ions, which promotes the adsorption of CO molecules [18].

\section{Gas-sensing properties}

We now consider the gas-sensing properties of $\mathrm{SnO}_{2}$ thick-film sensors. In order to determine the optimum operating temperatures, the response of the sensors to $\mathrm{CO}$ and $\mathrm{CH}_{4}(1000 \mathrm{ppm})$ are tested as a function of the operating temperature, as shown in Fig. 5. The response of the $\mathrm{SnO}_{2}$ (II) sensor to $\mathrm{CO}$ and $\mathrm{CH}_{4}$ is about 2.5 times higher, than the response of the $\mathrm{SnO}_{2}(\mathrm{I})$ sensor over a wide interval of working temperatures (see Fig. 5, $a, b$ ). The response maxima of the $\mathrm{SnO}_{2}$ (II) sensor to both gases are observed at lower temperatures, than iforn the $\mathrm{SnO}_{2}(\mathrm{I})$ sensor. The former has the maximum response to $\mathrm{CO}$ at a lower operation temperature, than to $\mathrm{CH}_{4}$. In the interval of temperatures from 350 to $375^{\circ} \mathrm{C}$, the highest difference between the responses of the $\mathrm{SnO}_{2}$ (II) sensor to $\mathrm{CO}$ and $\mathrm{CH}_{4}$ is observed. This operation mode is suitable for the selective detection of carbon monoxide.

Further, we measured changes in the sensor resistance at different concentrations of $\mathrm{CO}$ at the optimal operation temperature. Figure 6 shows the dependences of the electric resistance of the sensors on the concentration of $\mathrm{CO}$ in air. The $\mathrm{SnO}_{2}$ (II) sensor is characterized by a higher sensitivity to $\mathrm{CO}$ as compared with the $\mathrm{SnO}_{2}(\mathrm{I})$ sensor. Carbon monoxide can be detected by the $\mathrm{SnO}_{2}$ (II) sensor at concentrations smaller than $10 \mathrm{ppm}$.

The gas-sensing properties of the $\mathrm{SnO}_{2}$ (II) sensor are caused, on the one hand, by structural features of the $\mathrm{SnO}_{2}$ powder. The small size of $\mathrm{SnO}_{2}$ particles
( $d=5.5 \mathrm{~nm})$, which is comparable with the doubled thickness of the space-charge layer $(L \approx 3 \mathrm{~nm})$ [7], provides a high sensitivity of the $\mathrm{SnO}_{2}$ (II) sensor to reducing gases. The high surface area of the powder promotes the absorption of gases. On the other hand, surface sulfate groups increase the strength of the Lewis acid sites and promote the CO adsorption on the oxide surface.

\section{Conclusions}

$\mathrm{SnO}_{2}$ powders were synthesized from tin(II) sulphate by different routes. The preoxidation of a $\mathrm{SnSO}_{4}$ powder with concentrated $\mathrm{H}_{2} \mathrm{SO}_{4}$ prior to the hydrolysis stage allowed us to obtain the $\mathrm{SnO}_{2}$ powder, which is characterized by the $5.5-\mathrm{nm}$ average particle size and a high surface area $\left(70.4 \mathrm{~m}^{2} / \mathrm{g}\right)$ after the calcination at $600{ }^{\circ} \mathrm{C}$. The high concentration of $\mathrm{SO}_{4}^{2-}$ groups is observed on the surface of this sample. The thickfilm $\mathrm{SnO}_{2}$ (II) gas sensor is characterized by a higher response to $\mathrm{CO}$ and $\mathrm{CH}_{4}$ gases and a lower optimal working temperature as compared to the $\mathrm{SnO}_{2}(\mathrm{I})$ sensor. The $\mathrm{SnO}_{2}$ (II) sensor can be used for the detection of CO concentrations smaller, than $10 \mathrm{ppm}$. The improvement of the gas sensing properties of $\operatorname{tin}(\mathrm{IV})$ oxide layers is caused by their structural features and the effect of $\mathrm{SO}_{4}^{2-}$ ions on the adsorption properties of the oxide surface.

This work was performed within the framework of an international Ukrainian-Belarusian grant (Belarusian RFFR grants No. X21УКРГ-002).

1. M. Batzill, U. Diebold. The surface and materials science of tin oxide. Prog. Surf. Sci. 79, 45 (2005).

2. W. Göpel, K.D. Schierbaum. $\mathrm{SnO}_{2}$ sensors: current status and future prospects. Sens. Actuator B Chem. 26, 1 (1995).

3. D. Kohl. Surface processes in the detection of reducing gases with $\mathrm{SnO}_{2}$-based devices. Sens. Actuator. 18, 71 (1989).

4. G. Martinelli, M. C. Carotta. Thick-film gas sensors. Sens. Actuator B Chem. 23, 157 (1995).

5. S.P. Patil, V.L. Patil, S.S. Shendage, N.S. Harale, S.A. Vanalakar, J.H. Kim, P.S. Patil. Spray pyrolyzed indium oxide thick films as $\mathrm{NO}_{2}$ gas sensor. Ceram. Int. 42, 16160 (2016).

6. D.C. Pugh, S.M. Hailes, I.P. Parkin. A gas-sensing array produced from screen-printed, zeolite-modified chromium titanate. Meas. Sci. Technol. 26, 085102 (2015).

7. N. Yamazoe. New approaches for improving semiconductor gas sensors. Sens. Actuator B Chem. 5, 7 (1991). 
8. C. Xu, J. Tamaki, N. Miura, N. Yamazoe, Grain size effects on gas sensitivity of porous $\mathrm{SnO}_{2}$-based elements. Sens. Actuator B Chem. 3, 147 (1991).

9. S.M. Badalyan, M.N. Rumyantseva, S.A. Nikolaev, A.V. Marikutsa, V.V. Smirnov, A.S. Alikhanian, A.M. Gaskov. Effect of $\mathrm{Au}$ and $\mathrm{NiO}$ catalysts on the $\mathrm{NO}_{2}$ sensing properties of nanocrystalline $\mathrm{SnO}_{2}$, Inorg. Mater. 46, 232 (2010).

10. D. Wang, Y. Chen, Z. Liu, L. Li, C. Shi, H. Qin, J. Hu. $\mathrm{CO}_{2}-$ sensing properties and mechanism of nano- $\mathrm{SnO}_{2}$ thick-film sensor. Sens. Actuator B Chem. 227, 73 (2016).

11. K. Suematsu, K. Yamada, M. Yuasa, T. Kida, K. Shimanoe. Evaluation of Oxygen Adsorption Based on the Electric Properties of $\mathrm{SnO}_{2}$ Semiconductor Gas Sensors. Sensor. Mater. 28, 1211 (2016).

12. G.W. Wang, H. Hattori, K. Tanabe. The enhancement of acid strength and catalytic activity of $\mathrm{SnO}_{2}$ by the addition of sulfate ion. Chem. Lett. 12, 277 (1983).

13. H.C. Chiu, C.S. Yeh. Hydrothermal synthesis of $\mathrm{SnO}_{2}$ nanoparticles and their gas-sensing of alcohol. J. Phys. Chem. B 111, 7256 (2007).

14. K. Arata, M. Hino. Preparation of superacids by metal oxides and their catalytic action. Mater. Chem. Phys. 26, 213 (1990).

15. M. Takano, Y. Bando, N. Nakanishi, M. Sakai, H. Okinaka. Characterization of fine particles of the $\alpha-\mathrm{Fe}_{2} \mathrm{O}_{3}-\mathrm{SnO}_{2}$ system with residual $\mathrm{SO}_{4}^{2-}$ ions on the surface. J. Solid State Chem. 68, 153 (1987).

16. A.A. Bolzan, C. Fong, B.J. Kennedy, C.J. Howard. Structural studies of rutile-type metal dioxides. Acta Crystallogr. Sect. B 53, 373 (1997).
17. K. Nakamoto. Infrared and Raman Spectra of Inorganic and Coordination Compounds (John Wiley \& Sons, Ltd. 1986).

18. L.M. Kustov, V.B. Kazansky, F. Figueras, D. Tichit. Investigation of the acidic properties of $\mathrm{ZrO}_{2}$ modified by $\mathrm{SO}_{4}^{2-}$ anions. J. Catal. 150, 143 (1994).

Received 24.12.20

Е.А. Оводок, М.І. Івановсъка, Д.А.Котиков,

В.В. Кормош, П.П. Пилип, В.С. Біланич

СТРУКТУРНІ ХАРАКТЕРИСТИКИ

І ГАЗОЧУТЛИВІ ВЛАСТИВОСТІ НАНОРОЗМІРНИХ

МАТЕРІАЛІВ ДІОКСИДУ ОЛОВА,

СИНТЕЗОВАНИХ ІЗ СУЛЬФАТУ ОЛОВА

Досліджено структурні особливості, стан поверхні та газочутливі властивості нанокристалічних порошків $\mathrm{SnO}_{2}$, синтезованих із прекурсора $\mathrm{SnSO}_{4}$ різними методами. Для вимірювання характеристик зразків використовувалися методи XRD, TEM, BET i FTIR. Газові сенсори виготовлялися за товстоплівковою технологією з синтезованих порошків $\mathrm{SnO}_{2}$. Проведено вимірювання реакції отриманих датчиків на гази $\mathrm{CO}$ i $\mathrm{CH}_{4}$. Виявлено, що попередне окислення порошку $\mathrm{SnSO}_{4}$ концентрованою сірчаною кислотою перед гідролізом приводить до меншого розміру частинок, більшої площі поверхні, поліпшеної адсорбційної активності і більшої чутливості до відновних газів $\left(\mathrm{CO}, \mathrm{CH}_{4}\right)$ синтезованих матеріалів $\mathrm{SnO}_{2}$, ніж у випадку матеріалів $\mathrm{SnO}_{2}$, отриманих без стадії попереднього окислення.

Ключ о в $і$ слов в: $\mathrm{SnO}_{2}, \mathrm{SnSO}_{4}$, спектроскопія FTIR, товстоплівковий датчик, $\mathrm{CO}, \mathrm{CH}_{4}$. 